\title{
Pearls \& Oy-sters: Pembrolizumab-induced myasthenia gravis
}

Mohanad Algaeed, MD, Loulwah Mukharesh, MD, Morgan Heinzelmann, MD, and Henry J. Kaminski, MD

Neurology ${ }^{\circledR}$ 2018;91:e1365-e1367. doi:10.1212/WNL.0000000000006278
Correspondence

Dr. Kaminski

hkaminski@mfa.gwu.edu

\section{Pearls}

- Myasthenia gravis (MG) is an uncommon autoimmune, postsynaptic neuromuscular disorder, characterized clinically by variable and fluctuating weakness of ocular, bulbar, respiratory, and limb muscles.

- Targeted immunotherapies, directed against immune checkpoint modulators such as cytotoxic T-lymphocyte-associated protein 4 (CTLA-4), programmed cell death protein 1 (PD-1), and the PD-1 ligand (PD-L1), have become an important treatment modality for malignancies; while effective, these novel therapies have been associated with autoimmunerelated adverse events.

- Exacerbations of preexisting MG, as well as de novo presentations of MG, have been reported after the initiation of these agents; to date in the literature, pembrolizumab (Keytruda) has been associated with 3 exacerbations and 7 de novo presentations of MG.

- It is imperative to be acquainted with immune checkpoint modulator complications, as while they are effective in otherwise treatment-resistant malignancies, they may also produce severe adverse effects including exacerbation or induction of autoimmune disorders including devastating neurologic diseases and endocrinopathies.

\section{Oy-ster}

- Health care providers must have a high level of suspicion for MG among patients with weakness occurring soon after receiving checkpoint inhibitor therapy as early detection and treatment are likely to improve outcomes.

\section{Case report}

A 73-year-old man presented with fluctuating left eyelid droop and shortness of breath over 3 days. In the 3 weeks prior to presentation, he had received pembrolizumab for recurrent melanoma. He denied a history of similar complaints, and he had no personal or family history of autoimmune disease.

Examination demonstrated increasing ptosis with sustained upgaze and reduced neck flexion strength, but motor power was otherwise normal. He had no bulbar muscle weakness; negative inspiratory force was $\sim 20 \mathrm{~cm}$ of $\mathrm{H}_{2} \mathrm{O}$. The patient developed increasing respiratory insufficiency requiring intubation and mechanical ventilation. There was no evidence of infection, including negative Lyme antibody serology. Acetylcholine receptor binding antibody was 6.4 nmoL.

During the hospitalization, the patient received pyridostigmine but was subsequently held due to excess respiratory secretions and developed aspiration pneumonia, which was treated with antibiotics. 
The patient received $2 \mathrm{~g} / \mathrm{kg}$ of IV immunoglobulin (IVIg) therapy and was started on prednisone $60 \mathrm{mg}$ daily. Because of a lack of improvement, he underwent plasmapheresis for a total of 5 exchanges. After 5 weeks of hospitalization, the patient was transferred to an institution close to his home where he received another course of IVIg and continued prednisone treatment. Ultimately, the patient was successfully discharged home with home services.

\section{Discussion}

Treatment of malignancy has undergone a revolution with the development of immunotherapies that target immune checkpoints; specifically, CTLA-4, PD-1, and PD-L1. One example is pembrolizumab, a humanized monoclonal antibody against PD1 , a cell surface receptor that prevents T-cell activation and autoimmunity while promoting self-tolerance. ${ }^{1}$ It was initially approved for the treatment of metastatic melanoma, but additional approved uses now include gastric cancer, squamous cell head and neck cancer, non-small cell lung cancer, urothelial carcinoma, Hodgkin lymphoma, and microsatellite instabilityhigh cancer. While pembrolizumab and other checkpoint inhibitor therapies have proven to be effective and usually welltolerated, they have been associated with various adverse effects, including exacerbation or production of autoimmune disorders such as autoimmune thyroid diseases, adrenal insufficiency, type 1 diabetes mellitus, and Guillain-Barré syndrome. ${ }^{2,3}$

MG has been found to occur with pembrolizumab initiation, and both exacerbations of preexisting MG and de novo onset of MG have been described. To date, pembrolizumab has been associated with 3 exacerbations without any reported fatality, ${ }^{4-6}$ and 7 de novo presentations. ${ }^{7-12}$

The frequency of MG with checkpoint inhibitor treatment is not known. ${ }^{3}$ Immune-related adverse events can occur any time after treatment initiation, as it may also occur after treatment cessation. However, once initiated, it usually occurs within the first few weeks to months. ${ }^{3}$

Another PD-1 inhibitor example is nivolumab, which has been responsible for 6 de novo cases and 1 exacerbation of preexisting MG. ${ }^{13-17}$ Thus far, ipilimumab, which is an inhibitor of CTLA-4, has been linked to 5 de novo MG cases, where 1 case was in combination with nivolumab. ${ }^{18}$

A wide range of neurologic complications was reported in a large retrospective series that included 3,763 patients treated with nivolumab plus ipilimumab, or nivolumab alone. ${ }^{19} \mathrm{~A}$ total of 35 patients had substantial neurologic complications. ${ }^{19}$ Examples of such complications included encephalitis (a total of 5 cases), meningitis (a total of 5 cases), acute or chronic peripheral neuropathy (a total of 14 cases), and 1 case of MG. ${ }^{19}$

Treatment of immune checkpoint inhibitor-induced MG has typically involved acetylcholinesterase inhibitors or high- dose corticosteroids, ${ }^{5,7-11,14,16,17,20}$ with or without either IVIg $^{4,5,8,11,15,20}$ or plasmapheresis. $5,7,8,17,18,20$ These are the typical therapies for MG exacerbation and there is no information to suggest if there is a superior treatment for this drug-associated form of MG.

MG exacerbation is considered a high-grade life-threatening complication that requires collaborative decision-making with the patient, neurologist, and oncologist to consider permanent discontinuation of the checkpoint inhibitor. Health care providers should have a high level of suspicion of MG development or exacerbation with use of checkpoint inhibitors, as early detection and treatment will likely limit mortality and morbidity.

\section{Author contributions}

Dr. Algaeed: literature review, manuscript writing, concept analysis. Dr. Mukharesh: manuscript writing. Dr. Heinzelmann: literature review, manuscript writing. Dr. Kaminski: concept analysis, critical revision of the article, expert input.

\section{Acknowledgment}

Dr. Algaeed is a 2nd-year Neurology resident at the George Washington University Hospital. Dr. Mukharesh is a 3rd-year Neurology resident at the George Washington University Hospital. Dr. Heinzelmann is a 4th-year medical student at the George Washington University Hospital. Dr. Kaminski is the Chairman of the Neurology Department at the George Washington University and has provided clinical care and research in myasthenia gravis for nearly 30 years.

\section{Study funding}

No targeted funding reported.

\section{Disclosure}

The authors report no disclosures relevant to the manuscript. Go to Neurology.org/N for full disclosures.

\section{References}

1. Postow MA, Callahan MK, Wolchok JD. Immune checkpoint blockade in cancer therapy. J Clin Oncol 2015;33:1974-1982.

2. Wilgenhof S, Neyns B. Anti-CLTA-4 antibody-induced Guillain-Barre in a melanoma patient. Ann Oncol 2011;22:991-993.

3. Postow MA, Sidlow R, Hellmann MD. Immune-related adverse events associated with immune checkpoint blockade. N Engl J Med 2018;378:158-168.

4. Lau KH, Kumar A, Yang IH, Nowak RJ. Exacerbation of myasthenia gravis in a patient with melanoma treated with pembrolizumab. Muscle Nerve 2016;54:157-161.

5. Zhu J, Li Y. Myasthenia gravis exacerbation associated with pembrolizumab. Muscle Nerve 2016;54:506-507.

6. Phadke SD, Ghabour R, Swick BL, Swenson A, Milhem M, Zakharia Y. Pembrolizumab therapy triggering an exacerbation of preexisting autoimmune disease: a report of 2 patient cases. J Investig Med High Impact Case Rep 2016;4:2324709616674316.

7. Zimmer L, Goldinger SM, Hofmann L, et al. Neurological, respiratory, musculoskeletal, cardiac and ocular side-effects of anti-PD-1 therapy. Eur J Cancer 2016;60:210-225.

8. March KL, Samarin MJ, Sodhi A, Owens RE. Pembrolizumab-induced myasthenia gravis: a fatal case report. J Oncol Pharm Pract 2018;24:146-149.

9. Gonzalez NL, Puwanant A, Lu A, Marks SM, Živković SA. Myasthenia triggered by immune checkpoint inhibitors: new case and literature review. Neuromuscul Disord 2017;27:266-268.

10. Nguyen BH, Kuo J, Budiman A, Christie H, Ali S. Two cases of clinical myasthenia gravis associated with pembrolizumab use in responding melanoma patients. Melanoma Res 2017;27:152-154.

11. Alnahhas I, Wong J. A case of new-onset antibody-positive myasthenia gravis in a patient treated with pembrolizumab for melanoma. Muscle Nerve 2017;55: E25-E26. 
12. Makarious D, Horwood K, Coward JIG. Myasthenia gravis: an emerging toxicity of immune checkpoint inhibitors. Eur J Cancer 2017;82:128-136.

13. Polat P, Donofrio PD. Myasthenia gravis induced by nivolumab therapy in a patient with non-small-cell lung cancer. Muscle Nerve 2016;54:507.

14. Sciacca G, Nicoletti A, Rampello L et al. Benign form of myasthenia gravis after nivolumab treatment. Muscle Nerve 2016;54:507e9.

15. Chang E, Sabichi AL, Sada YH. Myasthenia gravis after nivolumab therapy for squamous cell carcinoma of the bladder. J Immunother 2017;40:114e6.

16. Shirai T, Sano T, Kamijo F, et al. Acetylcholine receptor binding antibody-associated myasthenia gravis and rhabdomyolysis induced by nivolumab in a patient with melanoma. Jpn J Clin Oncol 2016;46:86e8.
17. Kimura T, Fukushima S, Miyashita A et al. Myasthenic crisis and polymyositis induced by one dose of nivolumab. Cancer Sci 2016;107:1055e8.

18. Montes V, Sousa S, Guerreiro R, Carmona C, Pita F. Myasthenia gravis induced by ipilimumab in a patient with advanced melanoma. Eur J Nurol 2016; 23:548.

19. Larkin J, Chmielowski B, Lao CD, et al. Neurologic serious adverse events \& associated with nivolumab plus ipilimumab or nivolumab alone in advanced melanoma, including a case series of encephalitis. Oncologist 2017;22:709-718.

20. Loochtan AI, Nickolich MS, Hobson-Webb LD. Myasthenia gravis associated with ipilimumab and nivolumab in the treatment of small cell lung cancer. Muscle Nerve 2015;52:307e8. 


\title{
Neurology
}

\author{
Pearls \& Oy-sters: Pembrolizumab-induced myasthenia gravis \\ Mohanad Algaeed, Loulwah Mukharesh, Morgan Heinzelmann, et al. \\ Neurology 2018;91; e1365-e1367 \\ DOI 10.1212/WNL.0000000000006278
}

\section{This information is current as of October 1, 2018}

\section{Updated Information \& Services}

\section{References}

Citations

Subspecialty Collections

Permissions \& Licensing

Reprints including high resolution figures, can be found at: http://n.neurology.org/content/91/14/e1365.full

This article cites 20 articles, 2 of which you can access for free at: http://n.neurology.org/content/91/14/e1365.full\#ref-list-1

This article has been cited by 2 HighWire-hosted articles: http://n.neurology.org/content/91/14/e1365.full\#\#otherarticles

This article, along with others on similar topics, appears in the following collection(s):

All Clinical Neurology

http://n.neurology.org/cgi/collection/all_clinical_neurology

Autoimmune diseases

http://n.neurology.org/cgi/collection/autoimmune_diseases

Chemotherapy-tumor

http://n.neurology.org/cgi/collection/chemotherapytumor

Myasthenia

http://n.neurology.org/cgi/collection/myasthenia

Other toxicology

http://n.neurology.org/cgi/collection/other_toxicology

Information about reproducing this article in parts (figures,tables) or in its entirety can be found online at:

http://www.neurology.org/about/about_the_journal\#permissions

Information about ordering reprints can be found online:

http://n.neurology.org/subscribers/advertise

Neurology ${ }^{\circledR}$ is the official journal of the American Academy of Neurology. Published continuously since 1951, it is now a weekly with 48 issues per year. Copyright () 2018 American Academy of Neurology. All rights reserved. Print ISSN: 0028-3878. Online ISSN: 1526-632X.

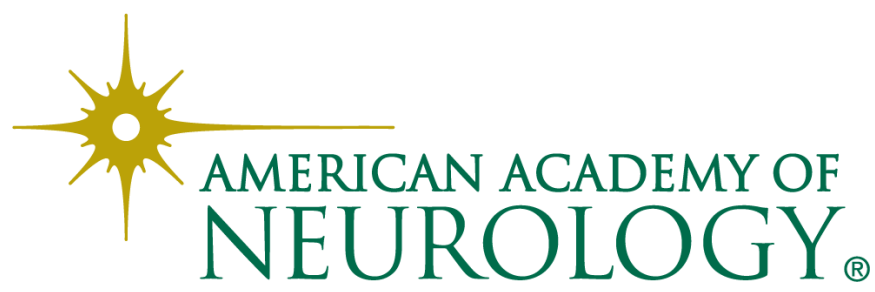

